\title{
Über das Fehlen der Makkabäerbücher in der äthiopischen Bibelübersetzung.
}

\author{
Von Alfred Rahlfs.
}

Während die Abessinier manche Apokryphen und Pseudepigraphen besitzen, die der Griechisch redenden Kirche abhanden gekommen sind, fehlen ihnen merkwürdigerweise die Makkabäerbücher gänzlich. ${ }^{\text {I }}$ Man schwankt, ob sie gar nicht übersetzt sind, oder ob die Übersetzung in der dunklen Zeit vor dem I3. Jahrhundert wieder verloren gegangen ist. LITTMANN hält ersteres für das wahrscheinlichste, ${ }^{2}$ und es wäre in der Tat höchst verwunderlich, wenn jede Spur einer ursprünglich vorhanden gewesenen Übersetzung verschwunden wäre, während doch so viele obskurere Werke geblieben sind. Gegen zufälligen Verlust spricht außerdem folgende Erwägung.

Die äthiopische Bibelübersetzung ist, wie ich in den beiden ersten Heften meiner Septuaginta-Studien (I 7984 ff. II 54 56) gezeigt habe, in den Königsbüchern und im Psalter mit B aufs engste verwandt. Obgleich daraus nicht folgt, da $B$ sie auch sonst überall ebenso eng mit $B$ verwandt sein müsse - denn die verschiedenen Bücher haben oft ihre verschiedene Geschichte gehabt -, so werden wir doch, wo sich sonst auffällige Übereinstimmungen zwischen Aeth und B zeigen, darin kein Spiel des Zufalls sehen können. Nun fehlen die Makkabäerbücher in B ebenso vollständig wie in Aeth, und sie sind, wie NestLe in der Theol. Literaturzeitung I895, Kol. I48f. aus der Lagenbildung der Handschrift bewiesen hat, in B auch niemals vorhanden gewesen. 'Sind sie aber in B absichtlich ausgelassen, so werden sie auch in Aeth nicht zufällig fehlen, sondern gleichfalls absichtlich ausgelassen sein.

Die gänzliche Auslassung der Makkabäerbücher geht, wie ich in

× Vgl. Fr. PrätoriUS, Artikel „Bibelübersetzungen, āthiopische“ in der Realencykl. f. prot. Theol. u. Kirche ${ }^{3}$, letzter Absatz.

2 Die Litteraturen des Ostens in Einzeldarstellungen, 7. Bd., 2. Abt.: Geschichte der christlichen Litteraturen des Orients, S. 228. 
meinem Aufsatz über "Alter und Heimat der vaticanischen Bibelhandschrift" in den Nachrichten der Ges. d. Wiss. zu Göttingen, Philol.-hist. K1. 1899, S. 72 gezeigt habe, auf Athanasius zurück. Es ist eine Haupteigentümlichkeit des von Athanasius im 39. Festbriefe aufgestellten Bibelkanons, daß er die Makkabäerbücher weder unter den eigentlich kanonischen Büchern, noch unter den „Vorlesebüchern“ nennt, also ganz ausschließt, während alle übrigen Kanonsverzeichnisse, soweit sie sich nicht auf den bloßen Kanon der Juden beschränken, wenigstens zwei Makkabäerbücher einschlieben. Athanasius steht aber auch $z \mathrm{u}$ der ältesten Kirche Äthiopiens in unmittelbarster Beziehung. Er hat, wie wir von ihm selbst erfahren (Apologia ad Constantium $\$ 29-31$ ), den Frumentius zum Bischof von Axum geweiht, s. DillmanN, Zur Geschichte des Axumitischen Reichs im vierten bis sechsten Jahrhundert (in den Abhandlungen der Akad. d. Wiss. zu Berlin 1880), S. Iof. So kann es uns nicht wundernehmen, wenn athảnasianische Tradition den ältesten Bibelkanon der Äthiopen bestimmt hat, und es ist ein merkwürdiges Zeugnis für die Zähigkeit, mit der eine solche Tradition, schließlich gewiß ganz unbewußt, nachwirken kann, daß der äthiopische Bibelkanon trotz der vielen Änderungen, die er im Laufe der Zeit erlitten, und trotz der Pseudepigraphen, die er ganz gegen die Praxis des Athanasius aufgenommen hat, doch hinsichtlich der Makkabäerbücher auf dem alten Standpunkte stehen geblieben ist. $x$

x Über junge Versuche, diese Lücke auszufüllen, s. PrätoriUs und LitTManN a. a. O. 